able for the historical investigator, and from them may be gathered many essential details of history.

In a monumental collecting project of this sort a number of problems confront the collector. Certain items are so scarce that it takes a long time to round them up for filming, even if the location is known. The hunting process itself makes items turn up too late, sometimes, to use in normal sequence. To take care of these and a number of other contingencies the compiler of the Supplement has included a most useful addenda section which takes care of a number of unavoidable omissions and happy discoveries since the Guide was published.

Many research institutions will want to add various segments of this monumental collection of basic documents on film; indeed, a number of institutions may want to purchase the whole collection as a unit. Purchase inquiries should be directed to the Photoduplication Service of the Library of Congress.

This review note would be incomplete without generous praise for the zeal, energy, and prodigious scholarship exerted by the collector, compiler, and editor, William Sumner Jenkins. $\mathrm{He}$ is an unquestionable authority in his field. His position as teacher and director of research in government and political science is all the stronger for his assiduous study of the basic documents. $-G$. F. Shepherd, Jr., Cornell University Library.

\section{Subject Headings}

Subject Headings; a Practical Guide. By David Judson Haykin. Washington, D.C., U. S. Government Printing Office, I95I. v, 140p. \$.70.

Mr. Haykin deserves the thanks of catalogers and teachers of cataloging for this well written and well printed volume on a subject on which little literature is available. The statements of principles are clear, the examples well chosen. The principles themselves are generally sound, although the Library of Congress does not always follow them consistently. Mr. Haykin disarms criticism to some extent by stating that "the principles and rules of practice here presented represent, in many instances, what is desirable, rather than what has actually been achieved." This disclaimer seems too general, however, to cover the failure to discuss the variations and inconsistencies in LC headings which unduly complicate the explanation of subject headings to the library user.

After a brief theoretical introduction the use of references to relate the various scattered headings is described. There follows a chapter on the form of the heading-simple, inverted, phrase, or compound. There is here, however, no discussion of the validity of the inverted form of heading. If the first principle of a good subject heading is usage, and if the dictionary catalog does not recognize any classification in the arrangement of headings, then the use of an inverted heading "in order that it may appear in the catalog next to other headings beginning with that noun" should be more elaborately justified. On page 24 the lack of a reference "Heretics. See Heresies and heretics" is excused on the plea that no other headings would intervene. Actually two subjects "Heresy" and "Heresy (Canon law)" as well as all titles beginning with the words Heresies and Heresy, intervene.

The fifth to seventh chapters deal with subdivisions and personal and geographic names. There is no general discussion of the type of material which takes a geographic subdivision under subject and that which takes a subject subdivision under place name, a distinction which is frequently difficult to explain. On page 39 there is a sentence discussing the advantage of the form "Goethe as theater director" over a possible "Goethe, Johann Wolfgang von-As theater director," but no reference to the fact that in Appendix $\mathrm{G}$ the forms "Shakespeare, William-Biography-As an actor" and "Lincoln, Abraham-As a lawyer" are listed.

A brief chapter discusses the over-extended use of duplicate entries which add their bit to the size of our catalogs. It is fully recognized that these have been used too frequently and the tendency is to replace them with a single entry. The relations of subject headings to author entries and added entries is next taken up, with the relation of the subject catalog to the shelf list, the forms of subjects for special libraries or special departmental catalogs, problems of filing, and procedures and personnel in the subject cataloging field. Appendixes containing various special lists of interest in subject heading work (omitting, however, the subdivisions used under place names) complete the work.

As a general introduction to the subject 
this is excellent. For teaching purposes or as a working tool one would like a more detailed treatment of particular problems. It is remarkable that $\mathrm{Mr}$. Haykin never refers to to the work of Ansteinsson in the third part of the Vatican Code, where rules for the use of subject headings in particular situations have been codified and made available. This is an almost indispensable supplement to the present discussion of general principles. It is only as one gets to a study of particular rules that the need for an explanation of such forms as "Art-France" and "Art, French," of the variations "French poetry," "Hymns, French;" "Bessel's functions," "Lamé's functions," "Functions, Abelian," become apparent. It is to be hoped that Mr. Haykin, having succeeded so well in presenting the general, will be able to give us the particular also, and so provide a really practical guide to the application of these principles. $-W y$ llis E. Wright, Williams College Library.

\section{ACRL Monographs, No. 3}

The Establishment of Staff Requirements in a Small Research Library. By Saul Herner, and M. K. Heatwole, librarians at Johns Hopkins University

A well-written case-study illustrating a method of library personnel administration which can be applied to the small college library, as well as to special libraries and the subject departments of large university and research libraries.

Send fifty cents $(50 \phi)$ in stamps or coin to

\section{Disserfation Abstracts (Formerly MICROFILM ABSTRACTS) EXPAND YOUR REFERENCE SERVICE \\ \$6.00 PER YEAR, SIX ISSUES SINGLE COPIES $\$ 1.50$ \\ SUBSCRIBE NOW!

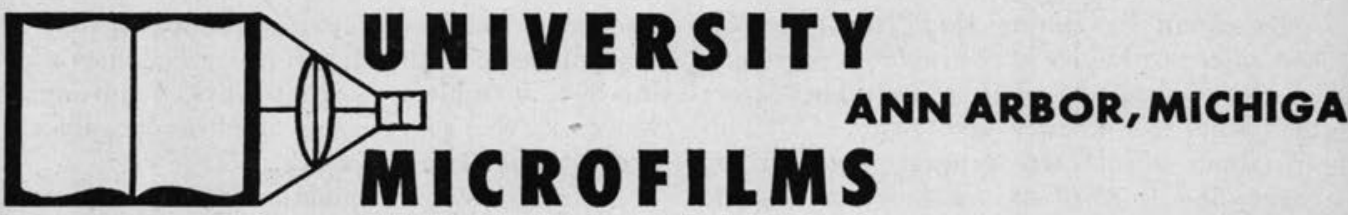

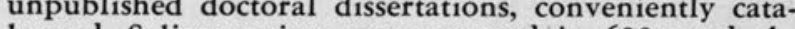 logued. Salient points are presented in 600-word ab- stracts - complete dissertations available in microfilm or page copy form. Twenty-five leading institutions have now approved and use microfilm publication for doctoral dissertations. Abstracts found only in Disser- tation Abstracts. Subscribe now. \\ A collection of abstracts of otherwise}

